\title{
Impact of Disasters on Public Health in Pakistan
}

\author{
Article by Muhammad Khan Tunio \\ MPH, Texila American University, Pakistan \\ Email: mhammadkhan9413@texilaconnect.com
}

\section{Context:}

Pakistan is a state of four provinces, Punjab, Sindh, Khyberpakhtunkhawa and Baluchistan and it contains four federal territories, Islamabad, FATA (Federally administered tribal areas), AJK (Azaad Jamu and Kashmir) and Gilgat Balitistan. Pakistan’s neighbor countries are India, China, Iran and Afghanistan.

With an estimated more than 180 million population, Pakistan is the sixth biggest country in the world and second largest Muslim country after Indonesia, with life expectancy of 65 years with literacy rate of 49 percent (63 male and 36 female) and HDI (Human development Index) ranks of Pakistan is 141 of 182 and considered as an under developed country.

The despite of 33 of its 67 years under military rule the situation of security in the country is complex with multiple overlapping threats from bordering countries like Afghanistan and India. This increase in the magnitude of its natural disasters like floods, earthquake and droughts and whole situation explains Pakistan as a disaster-prone country. Some unseen disasters like Mega flood in 2010 (20 million affected and destroyed two million homes, 514 health facilities destroyed, almost a size of England land inundated), 2011 and 2012 heavy monsoon rains, 2013 and 2014 military operations against terrorism in the areas near to Afghan border left millions homeless (Around four million IDPs and refugees, including 2005 earthquake) and 2014 floods in KPK and Punjab are a real issue with the limited resources of state which are prioritized to address emergencies.

The Health indicators were poor before the floods and terrorism, counter war as MMR 230 (190-280) per 100000 live births and 89 per 1000 live births in under five children. The flood dragged population further down on the socioeconomic Quintiles and these disasters worsened their life style and left a high impact on public health of the people. High Global acute malnutrition rates, stunting rates, psychiatric shocks due to frequent and ongoing terrorist attacks and displacement had affected the population, prone to the disasters. This situation clearly hurdles country to show standard and required progress on millennium development goals.

\section{Objectives:}

To review the following indicators in the current health system of Pakistan:

1. To know the achievement of the MDGs before disasters 2010-2014 in the Pakistan.

2. To know the short term and long term consequences on the public health and population.

3. To know the burden of cases in the public health and possible achievements against the MDGs

\section{Content details}

\section{Overview of disease trends in the disasters}

As per Haider Wadaich in the report of flood effects on public health, just in between August 2010 and September 20106.2 million consultations for gastroenteritis, respiratory infections, malaria and dermatologic conditions were reported to WHO from 50 of 64 affected districts, with countless more predicted to fall sick in the period that followed. Surveillance data from flood-affected districts interprets that WHO reported mounting cases of Crimean-Congo hemorrhagic fever, dengue fever, cholera, falciparum malaria, measles and polio. 
Pakistan is one of only four countries where polio remains endemic, adverse impact on polio eradication has been substantial. Eradication remains a challenge due to the complex situation exacerbated by the war in Afghanistan, insurgency in Pakistan and the resulting mass movement of people. By 9 November 2010, Pakistan accounted for about 62\% (111 cases) of all 180 polio cases from endemic countries, and more new cases were from floodaffected areas. However, WHO increased efforts at delivering vaccination services in 45 flood-affected districts and, due to enhanced cooperation between the Pakistan Expanded Program on Immunization (EPI), WHO and UNICEF, national immunization days went ahead as planned.+

Apart from this routine disease trends and the injuries in the war and counterterrorism activities is additional to the situation.

\section{Malnutrition trends and analysis}

The Government with the health of the Agha Khan university conducted a nationwide survey to measure the prevalence of malnutrition in the country, hidden hunger (micronutrients deficiency), to know the core indicators of the food security in the country and its impact on the nutritional status of the populations. 50.4\% mothers are maternal anemic, $42.5 \%$ women are facing Vitamin-A deficiency, $43.7 \%$ children under five years age are stunted, $15.1 \%$ children under five are wasted and $31.5 \%$ children under five years are underweight in the results of the NNS 2011 in Pakistan.

Following is the table of the results for the nutrition indicator in adults with BMI.

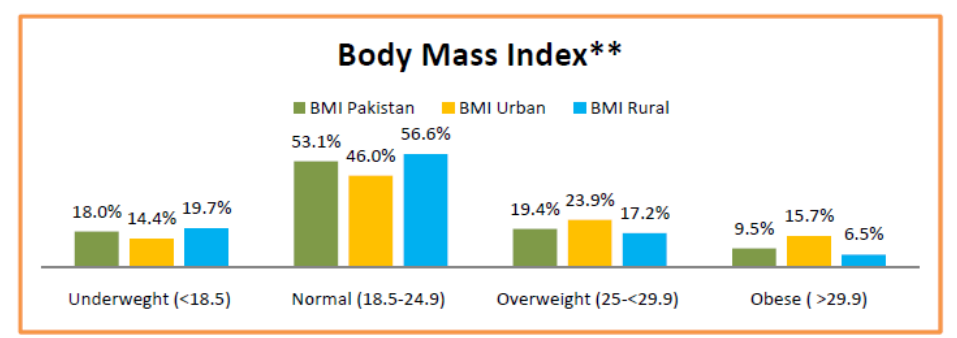

The above table shows the BMI results in Pakistan urban and rural areas. The interesting things in this table that underweight urban and the rural percentage difference is lower than the obese figure. If we compare overall figure for the normal in this index, the rural percentage is much better than the urban. The overweight and obese percentage is higher in urban due to their life style and different mode of the disasters in the cities than villages. The possible reasons for the high rates of overweight and obesity in urban areas are due to following possible reasons.

1. Less walking opportunity

2. More televisions and channels

3. High coverage of computer and internet

4. Fear of terrorism and unlawful activities restrict movement

5. Highly tensed situation due to terrorist attacks

6. Professional anxiety and fixed duty at location

\section{Impact of war against terrorism on economy of country}

Pakistan is one of the main victims and ranked $3^{\text {rd }}$ dangerous country to live due to frequent terrorist attacks and continual counter strategy. Pakistan stood against these militant forces that had their sanctuaries in areas at the borderline between Pakistan and Afghanistan. This position helps them to move in either country at different situations and plans. Pakistan waged war against terrorism from 2001 and that was the reaction part of 9/11. 


\begin{tabular}{|l|l|l|l|}
\hline \multicolumn{5}{|c|}{ Cost of War (2001-2011) ++ } \\
\hline \multicolumn{1}{|c|}{ Year } & Billion \$ & Billion PKRs & \% Change \\
\hline $2001-02$ & 2.669 & 163.9 & - \\
\hline $2002-03$ & 2.749 & 160.8 & 3.00 \\
\hline $2003-04$ & 2.932 & 168.8 & 6.70 \\
\hline $2004-05$ & 3.410 & 202.4 & 16.30 \\
\hline $2005-06$ & 3.986 & 238.6 & 16.90 \\
\hline $2006-07$ & 4.670 & 283.2 & 17.20 \\
\hline $2007-08$ & 6.940 & 434.1 & 48.60 \\
\hline $2008-09$ & 9.180 & 720.6 & 32.30 \\
\hline $2009-10$ & 13.560 & 1136.4 & 47.70 \\
\hline $2010-11$ & 17.830 & 1528.0 & 31.50 \\
\hline Total & $\mathbf{6 7 . 9 2 6}$ & $\mathbf{5 0 3 6 . 8}$ & - \\
\hline
\end{tabular}

Pakistan became allies of the USA and paid heavy prices and reality is if the situation in Pakistan is stable that impacts whole region. The adjacent table shows the extra expenditures on the defense of the country the cost of the counterterrorism in almost the last decade and half. This had a heavy cost to pay for the developing nation who struggles to meet the expenses of the regular department. Around 24 billion dollars are the expenditures of the last two years of war against terrorism. And not confirmed resources declare the total cost at the end of the year 2014 is above 102 billion dollars. This is budget and beside that a dedicated human resources engaged in it and many other indirect costs, which pull back the country to perform on MDGs as per standards. Detailed cost for last two year is in the annexure-III of economic survey of Pakistan for year 2013 and 2014.

\section{Progress on the millennium development goals}

After the review of the Pakistan Millennium Development Goals report 2013 by Pakistan planning and development commission, below table reveals the progress of the Pakistan against Millennium development Goals, which indicates only 3 indicators are achieved from goal 3, 4 \& 6 and some indicators are on track. Majority indicators are on track for the Goal 7. Remaining performance is off the track to achieve Goals against set targets.

\begin{tabular}{|l|l|}
\hline Millennium development Goals' overall progress \\
\hline Indicators & Status \\
\hline Goal 1: Eradicate Extreme Poverty and Hunger \\
\hline $\begin{array}{l}\text { Proportion of population below the calorie based food plus } \\
\text { non- food poverty line. }\end{array}$ & On Track \\
\hline Prevalence of underweight children under 5 years of age & Off Track \\
\hline $\begin{array}{l}\text { Proportion of population below minimum level of dietary } \\
\text { energy consumption }\end{array}$ & Off Track \\
\hline Goal 2: Achieve Universal Primary Education & \\
\hline Net primary enrolment ratio ( percent) & Off Track \\
\hline Completion/survival rate Grade 1 to 5 ( percent) & Off Track \\
\hline Literacy rate ( percent) & Off Track \\
\hline Goal 3: Promote Gender Equality and Women's Empowerment \\
\hline GPI Primary Education & Off Track \\
\hline GPI Secondary Education & Off Track \\
\hline Youth Literacy GPI & Off Track \\
\hline Share of Women in Wage Employment & Off Track \\
\hline Proportion of Seats held by Women in National Assembly & Achieved \\
\hline
\end{tabular}


South American Journal of Public Health

Special Edition May 2016

\begin{tabular}{|l|l|}
\hline \multicolumn{2}{|l|}{ Goal 4: Reduce Child Mortality } \\
\hline Under 5 Mortality Rate (Deaths per 1000 Live Births) & Off Track \\
\hline Infant Mortality Rate (Deaths per 1000 Live Births) & Off Track \\
\hline Proportion of Fully Immunized Children 12-23 Months & Off Track \\
\hline $\begin{array}{l}\text { Proportion of under 1 year children immunized against } \\
\text { measles }\end{array}$ & Off Track \\
\hline $\begin{array}{l}\text { Proportion of Children Under 5 Who Suffered from Diarrhea } \\
\text { in the Last 30 Days (Percent) }\end{array}$ & Achieved \\
\hline $\begin{array}{l}\text { Lady Health Worker's Coverage ( percent of target } \\
\text { population) }\end{array}$ & Off Track \\
\hline Goal 5: Improve Maternal Health & Off Track \\
\hline Maternal Mortality Ratio & Off Track \\
\hline Proportion of births attended by Skilled Birth Attendants & Off Track \\
\hline Contraceptive Prevalence Rate & Off Track \\
\hline Total Fertility Rate & Off Track \\
\hline $\begin{array}{l}\text { Proportion of women 15-49 who had given birth during last } \\
\text { years and made at least one antenatal consultation }\end{array}$ & \\
\hline Goal 6: Combat HIV/AIDS, Malaria and Other Diseases \\
\hline HIV prevalence among 15-49 year old pregnant women & On Track \\
\hline HIV prevalence among vulnerable groups & Off Track \\
\hline $\begin{array}{l}\text { Portion of population in malaria risk areas using effective } \\
\text { prevention and treatment measures }\end{array}$ & Off Track \\
\hline Incidence of TB/10,000 & Off Track \\
\hline TB cases detected and cured under DOTS & Achieved \\
\hline Goal 7: Ensuring Environmental Sustainability & On Track \\
\hline Forest Cover ( percent) & On Track \\
\hline Land Area Protected for Conservation of Wildlife ( percent) \\
\hline $\begin{array}{l}\text { GDP (in 1980-81 Rs.) per ton of } \\
\text { efficiency) }\end{array}$ \\
\hline Sulfur Content in High Speed Diesel \\
\hline $\begin{array}{l}\text { Proportion of Population with Access to Improved Water } \\
\text { Sources }\end{array}$ & On Track \\
\hline Proportion of Population with Access to Sanitation \\
\hline Proportion of Katchi Abadies Regularized & Off Track \\
\hline
\end{tabular}

Aforementioned table is taken from the Government Progress Report on MDGs for year 2013 and the reason for all Off track status are enlisted as below:

1. Natural disasters

a. Floods 2010 and 2014

b. Heavy Monsoon rains in 2011 and 2012

c. Drought conditions declared in the Sindh province's districts of Kohistan and deserts

2. Manmade disasters

a. War against terrorism and high number IDPs and refugees.

b. Terrorist attacks which destroy and harm he health facilities

c. Tribal, political and religious clashes 
These reasons and factors have halted the performance of the state on the MDGs. Natural disasters cannot be seen well ahead to mitigate but for manmade factors needs to be strategized.

\section{Recommendations}

\section{Short term}

1. Financial Aids from allies and UN agencies to strengthen house held level livelihood.

2. Increase taxes to meet immediate needs of agriculture and industrial elites.

3. Stop or minimize the response the war on the terrorism and tries to settle the displaced people.

\section{Long Term}

1. Quickly get results in the war against terrorism and make sure that Afghan remains stable.

2. The SMART contingency plan and build the capacity of the various departments. The high threshold of the capacity within departments will show minimum impact of disasters. This will improve the quality and quick response in the disaster time.

3. Villages need to be settled away from the flood prone areas.

4. Raise the taxes on the agricultural and industrial tycoons.

5. Government has to show the transparency and start to develop a mechanism to rely lesser on the financial aid.

\section{References}

[1.] ++ An article by Sardar Sikandar Shaheen from daily times, on Pakistan lost Rs 8,264 billion in 'war on terror'

http://www.dailytimes.com.pk/national/03-Jun-2014/pakistan-lost-rs-8-264-billion-in-war-on-terror

[2.] +Floods in Pakistan- a public health crisis by Haiderwadaich, Anita KM Zaidi and Kavita Patel, Bull World Health Organ. Mar 1, 2011; 89(3): 236-237.doi: 10.2471/BLT.10.083386

[3.] Impact of Afghan war on economy of Pakistan. Annexure III of economic survey of 2013 and 2014 Pakistan.

http://finance.gov.pk/survey/chapters_14/Annex_3.pdf

[4.] *** Government of Pakistan, Economic survey 2010-11, Report

http://www.finance.gov.pk/survey/chapter_11/Special\%20Section_1.pdf

[5.] * Ministry of planning, development and reforms commission Pakistan report 2013 on "Pakistan Millennium development goals.”

http://www.undp.org/content/dam/pakistan/docs/MDGs/MDG2013Report/UNDP-Report13.pdf

[6.] ** Planning commission, planning and development division Government of Pakistan. "National nutrition survey 2011” survey report.

http://pakresponse.info/LinkClick.aspx?fileticket=Ao4s-rwdFVI\%3D\&tabid=117\&mid=752 